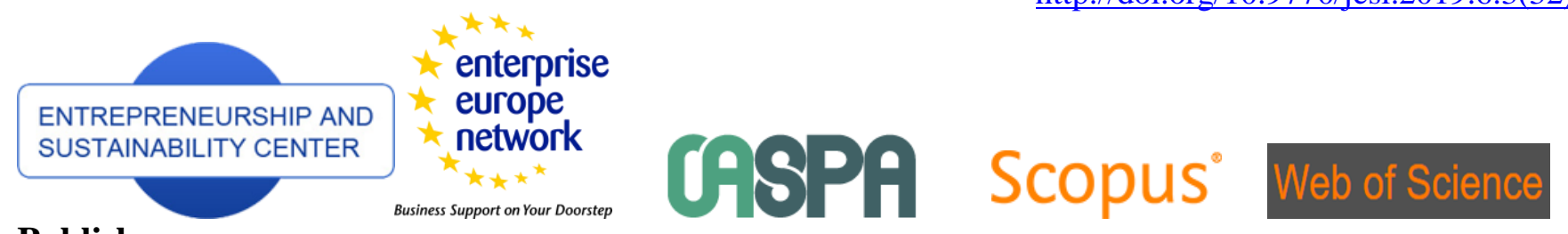

Publisher

Business Support on Your Doorstep

$\underline{\text { http://jssidoi.org/esc/home }}$

1) Clarivate

Analytics

\title{
THE PERCEIVED VALUE OF SOCIAL MEDIA MARKETING: AN EMPIRICAL STUDY OF ONLINE WORD OF MOUTH IN SAUDI ARABIAN CONTEXT*
}

\author{
Ahmed S. Ajina \\ Dean, College of Business Administration, Prince Sattam Bin Abdulaziz Universtiy, Al-Khar, \\ Saudi Arabia \\ E-mail: aajina@gmail.com
}

Received 16 November 2018; accepted 27 February 2019; published 30 March 2019

\begin{abstract}
Despite the dramatic increase in the use social media marketing and huge business investments allocated to online marketing, little is known about consumers' perceived value of social media marketing. The perceived value concept is key factor in traditional consumer behavior.However investigations into online channels have not been done intensively. The present work has succeeded in demonstrating the role of perceived value on online consumer behavior and its influences on online word of mouth (OWOM) and behavioral loyalty. Based on a sample of 525 respondents who were social media users, the study used Partial Least Squares (PLS) technique to analyze the data. The study has succeeded in filling various gaps of knowledge and literature. The gaps addressed by the present work includes aspects pertaining to perceived value of social media marketing, online word of mouth, behavioral loyalty on online channels, etc.
\end{abstract}

Keywords: Consumer behavior; Social media marketing; Online word of mouth; Perceived Value; Customer Loyalty

Reference to this paper should be made as follows: Ajina, A. S. 2019. The perceived value of social media marketing: an empirical study of online word-of-mouth in Saudi Arabian context, Entrepreneurship and Sustainability Issues 6(3): 1512-1527. https://doi.org/10.9770/jssi.2019.6.3(32)

JEL Classifications: M31

*This project was supported by the Deanship of Scientific Research at Prince Sattam Bin Abdulaziz University under the resarcch project \# 2016/01/5721

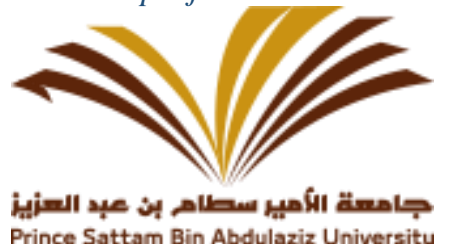




\section{ENTREPRENEURSHIP AND SUSTAINABILITY ISSUES}

ISSN 2345-0282 (online) http://jssidoi.org/jesi/

2019 Volume 6 Number 3 (March)

http://doi.org/10.9770/jesi.2019.6.3(32)

\section{Introduction}

Social media platforms provide immense opportunities for businesses to achieve their marketing objectives at considerably low costs. Recently, social media marketing has received increasing attention among industry and academic circles. Reflecting this reality, De Vriesa, Genslera and Leeflanga (2012) opines that more than half of social media users are following their favorite brands on twitter. Moreover the worldwide spending on social media marketing is estimated to be USD 35.98 billion in 2018 (Kusumasondjaja, 2018). This shows that social media marketing has opened up a whole now vista of opportunities.

With dramatic increase in the use of social media channels, followed by huge investments in social media marketing, there definitely is a need for revisiting marketing relationships. The geographic disparate of online communities allows sharing of experiences among different cultural and ethnic groups. This distinct feature is expected to yield new inspirations and dimensions in the decision making process. As a direct consequence of this, there is likely to be marked change in perceptions, expectations and satisfaction level of consumers; especially when they are exposed to varying and better business practices and experiences.

Contradictory findings have been reported by social media marketing researchers (Duan, Gu\&Whinston, 2008). These findings have raised questions as to whether the current changes in contexts have affected the results of empirical examinations. A classical example is the assumption that the same causal relationships in traditional marketing are also applicable to online consumer behaviors. This aspect, highlighted by Duan, et al, (2008) in their seminal work calls for further investigation of the influence of online word of mouth (OWOM) in consumers' buying decisions.

\section{Review of Literature}

Word-of-mouth (WOM) has been identified as a strong information transmission tool since time immemorial (Ellison and Fudenberg, 1995; Godes and Mayzlin 2004; Maxham an dNetemeyer 2002), which has successfully been used by businesses to influence consumers. The uniqueness of WOM over traditional marketing has been highlighted by Duana, Gu and Whinston (2008), when they stated that "WOM leads to more product sales, which in turn generate moreWOM and the nmore product sales". However, the conventional WOM has certain inherent limitations, as it is effective only across limited social contact boundaries. Further, its influencediminishes rapidly across time and distance (Bhatnagar and Ghose, 2004).

With the advancement of informationtechnology (IT), emergeda host of online social networking sites and platforms. The online networking sites have drastically changed and disrupted the way marketing is now done. These sites have succeeded in transcendingmany of the limitations oftraditional WOM (Laroche,Yang, McDougalland Bergeron, 2005) and have given a new dimension to social media marketing. The potential of social media marketing has made business to accord top priority. With the turn of the century online WOM was identified as a tool that could be highly successful in being leveraged as a successful marketing tool (Dellarocas, 2003).

The review of literature for the study considers and involves four main knowledge areas which represent the main constructs of the study. These areas identified are social media marketing (De Vriesa et al., 2012), perceived value (Halbrook, 1994; Sánchez-Fernández \& Iniesta-Bonillo, 2007), loyalty (Kotler \& Armstrong, 2008; Mandhachitara, et al., 2011; Rundle-Thiele, 2005), and word of mouth (Duan, et al, 2008; Verhagen, Nauta\& Feldberg, 2013).The following section presents a fair view of these four identified areas. 


\section{ENTREPRENEURSHIP AND SUSTAINABILITY ISSUES}

ISSN 2345-0282 (online) http://jssidoi.org/jesi/

2019 Volume 6 Number 3 (March)

http://doi.org/10.9770/jesi.2019.6.3(32)

\section{Social Media Marketing}

Though of recent origin, sufficient literature has accumulated about the various aspects and dimensions of social media marketing. Social media marketing is the "online applications, platforms and media which aim to facilitate interactions, collaborations and the sharing of content" (Kim and Ko, 2012 p.1480). The applications or platforms could include Twitter, Facebook, Instagram, Snapchat, etc. The contents of these applications appear in number of forms like texts, videos, photos, etc. A study by Kim and Ko (2010) found a significant influence of social media marketing on brand reputations. A high influence of social media marketing informationin consumers' purchase decisions, as compared to the traditional social influence was also found by Kim and Ko (2012). Consumers' emotional attachment through social media platforms was examined by Dholakia and Durham (2010).

With the emergence and manifold growth of web 2.0 implications in marketing, a number investigation have attempted to study brand popularity by considering the number of likes or favorites given to a specific post (De Vriesa et al., 2012). However, this technique has a number of limitations. For instance, though the number of likes can be used as an indication of consumers' attitudes towards products and services, it only measures their affective component of attitudes. This does not discuss the behavioral component exhibited in the social media platforms. It has been identified that post sharings or retweets provide meaningful feeds about consumers' behavioral attitudes like behavioral loyalty and online word of mouth (OWOM). This marketing tool is now playing increasingly significant role in the current day consumer purchase decisions (Duan, et al, 2008).

It would now be imperative to have a fair discussion about OWOM.

\section{Online WOM (OWOM)}

OWOM is a new marketing tool in the hands of the retailers that has emerged in the digital age, which can be successfully leveraged to reach the desired consumer groups, as well as to strategically influence consumer opinions (Chen and Xie 2004; Dellarocas, 2003; Senecal and Nantel 2004). OWOM is defined as informal communications among online communities about certain products, services, or brands through which they share their experiences and perceptions (Cheung and Lee, 2012; Eastet, al., 2007). Literature about OWOM suggests that it is a tool that shifts the control of communication message from the firm to its consumers. In the initial stages it was generally perceived as threat to marketing efforts, as there could be negative messages (Verhagen et al, 2013). But with the passage of time and the potential of OWOM becoming evident, the attitude towards OWOM underwent a sea change, and it now holds prime position in almost all promotional and marketing activities.

OWOM has also been referred to by many researchers and marketers as e-WOM (Andreassen and Streukens 2009; Cheung et al. 2009, Dhar and Chang 2009; Trusov, Bucklin, and Pauwels 2009). A few other have used the both interchangeably (King, Racherla and Bush, 2014). A fair review of the available literature presents the fact that, but for the nomenclature, there exists scant difference between the two. Further, OWOM seems to be used my majority of researchers. Hence in the present work, the researchers chose to use OWOM.

OWOM enables consumers to interact socially, to exchange experience through computer-mediated conversations (Blazevic et al. 2013; King, et al, 2014). Various types of OWOM communications have been identified in literature. This is spread over a host of platforms and types. Some of the types of OWOM communication include blogs (Dhar and Chang 2009; Kozinets, De Valck, Wojnicki. and Wilner, 2010); discussion forums (Andreassen and Streukens 2009); product reviews (Tirunillai and Tellis 2012); social networking sites (Trusov, Bucklin, and Pauwels 2009); UseNet groups (Godes and Mayzlin 2004; Godes and Silva, 2012); etc.King, et al, 


\section{ENTREPRENEURSHIP AND SUSTAINABILITY ISSUES}

ISSN 2345-0282 (online) http://jssidoi.org/jesi/

2019 Volume 6 Number 3 (March)

http://doi.org/10.9770/jesi.2019.6.3(32)

(2014) identified six characteristic of WOM - Enhanced Volume, Dispersion, Persistence andObservability, Anonymity and Deception, Salience of valence and Community Engagement.

Substantial empirical results exist to prove a positive relationship between OWOM andproduct sales (Chevalier and Mayzlin, 2006; Li and Hitt, 2008; Liu, 2006).It was also observed that managing positive WOM would help reducing promotional expenditures and creatinga form of community support for their respective brands (Reichheld and Sasser, 1990). Positive WOMwas found to have a significant influence on decision making process (Verhagen, Nauta and Feldberg, 2013). Söderlund (1998; p.172), defines positive WOM as:

"the extent to which a customer informs friends, relatives and colleagues about an event that has created a certain level of satisfaction".

Empirical evidence exists to prove that products havingmultiple positive reviews often tend toattract still more such reviews (Moe and Schweidel, 2012). A number of researchers have classified WOM as a behavioral indicator which arises as a direct consequence of an emotional attitude and an incidence of repeat purchase by friends and families (Verhagen, Nauta and Feldberg, 2013).

Research about WOM and customer satisfaction is inconclusive, as it has thrown up contradictory results. For example, Fisk, Brown, Cannizzaro, and Naftal, (1990) reported a negative relationships between customers satisfaction and WOM due to asymmetrical factor between negative and positive satisfactions i.e. negative satisfactions generate stronger reactions compare to positive satisfactions (Söderlund, 1998). Similarly, Taylor (1991) indicated that negative satisfaction creates emotional signals for certain reactions whereas positive satisfactions usually do not. On the other hand, Holmes and Lett (1977) reported a stronger influence of positive satisfaction on WOM compared to negative satisfactions. The is due to "Pollyanna Principle" which posits that people are more likely to remember and response to pleasant memories compare to unpleasant experiences (Clow, \& Seshadri, 2015 and Venkataramani, Labianca, \& Grosser, 2013).

A word of caution has also been sounded by researchers regarding OWOM. For instance Cui, Lui, and Guo(2012) and Mizerski (1982) identified a form of negativity bias. They found that in case consumers are neutral while reviewing, the available negative reviews are found to gain more salience than the available positive reviews. This could cause distortion and disadvantage to the promotion and marketing activities. These contradictory findings call for more investigations for the on these relationships.

The present study intends to focus on the influence of OWOM on consumers perceived value and its role on influencing behavioral loyalty. Despite substantial growth on the number of empirical works about social media marketing and increase in number of marketing journals associated with interactive marketing, there exists scant knowledge about perceived value of social media and its influence of the behavioral attitudes such as loyalty and OWOM.

\section{Perceived Value}

Considerable attention has been provided by academics and professionals to the concept of perceived value (PV) since its emergence in the 1980s (Halbrook, 1994). This concept was classified as priority research area by Marketing Science Institute between the years 2006 and 2008 (Sánchez-Fernández \& Iniesta-Bonillo, 2007). According to Wang et al., (2004), its importance stems from the economic and psychological dimensions of the concept; and its ability to generate competitive advantages for businesses. It was reported by number of researches as a key construct to understand consumer behavior (Wang et al, 2004). A number of researchers have empirically observed significant relationships between perceive value and behavioral loyalty. However PV has been subjected to vast definitional debates and had been a concept of misinterpretation that was overused and misused (Sánchez-Fernández et al, 2007). 


\section{ENTREPRENEURSHIP AND SUSTAINABILITY ISSUES}

ISSN 2345-0282 (online) http://jssidoi.org/jesi/

2019 Volume 6 Number 3 (March)

http://doi.org/10.9770/jesi.2019.6.3(32)

One of mostly common agreed on definition of PV is that it is "the overall assessment of the utility of a product based on a perception of what is received and what is given" (Zeithaml, 1988, p. 14). This simply means the trade-off between what is gained and what is given (Monroe, 1990). Despite the importance of PV in the investigation of consumer behavior, only scant focus have been provided to the perceived value of social media marketing.

The Utility Theory (Fishburn, 1970) has been predominantly used to build the theoretical foundation of PV as it provides a justified explanation of consumers' evaluation procedures and decision making processes. The theory suggests that consumers' behavioral decisions while considering alternative products or services are made according to the utility (benefits) maximizations. Therefore, this study assumes thatinvestigating the perceived value of social media marketing will help in better understand its influence of behavioral loyalty and OWOM.

\section{Loyalty}

Customers loyalty which is one of the most well-established and well-recognized marketing concepts can be defined as "customer's attitude and behavioral intentions towards the goods/service offered and actual repeat purchasing behavior" (Mandhachitara et al., 2011, p. 123; Kotler and Armstrong, 2008). Previously, customers' loyalty used to be assessed by behavioral loyalty only i.e. repeat purchase and recommendations to friends and families (Mandhachitara et al., 2011; Rundle-Thiele, 2005). However, this conceptualization fails to distinguish between real and fake loyalties (Oliver, 1997). Loyalty is posited to be regulated by consumers' value and the link between perceived value and loyalty was established by number of researchers (Sirdeshmukh, Singh, Sabol, 2002; Yang and Peterson, 2004; Li and Green, 2012; Chahal and Kumari, 2011). However, there are lack studies that investigated this relationship in the context of social media and in web 2.0 applications. Therefore, this study proposed to examine these relationships in such an emergent dynamic context.

\section{Identified Gaps}

A review of literature identified the following gaps, which is sought to be addressed by the present work:

1. Scant attention has been paid to investigate the concept of social media marketing in developing counties, especially Saudi Arabia.

2. Only little is known about the perceived value of social media marketing and its influence onbehavioral loyalty.

3. There exists wide potential towards investigating the relationship between OWOM and behavior loyalty. This will help in finding out whether the online consumer behavior follows the same pattern as that of the traditional WOM.

4. There exists scant literature about the perceived value of social media marketing and the OWOM. An examination towards this direction is expected to provide new insights to the academic field and business practices.

\section{Research Objectives}

The identified knowledge gaps based on the review of literature has enabled in developing the aim of this study. The study aims to examine the perceived value of social media marketing towards consumer behaviors. It also intends to look into the influence of OWOM on behavioral attitudes. Based on the review of literature and the aims of the study, the following objectives are identified for the study:

1. To examine the perceived value of social media marketing in the Saudi Arabian context.

2. To develop a conceptual model that relates the perceived value of social media into OWOM. 
ENTREPRENEURSHIP AND SUSTAINABILITY ISSUES

ISSN 2345-0282 (online) http://jssidoi.org/jesi/

2019 Volume 6 Number 3 (March)

http://doi.org/10.9770/jesi.2019.6.3(32)

3. To investigate the role of OWOM on behavioral loyalty

4. To provide appropriate insights to business practitioners that will help in the enhancement of the practices of social media marketing in Saudi context.

\section{Hypotheses for the study}

Based on the thorough review of literature and the objectives identified for the stud, the following hypotheses were identified for the study:

$\mathrm{H}_{1}$ : There is significant positive relationship between Customer engagement and Perceived Value of social media marketing.

$\mathrm{H}_{2}$ : There is significant positive relationship between customer engagement and online word of mouth.

$\mathrm{H}_{3}$ : There is significant positive relationship between customer engagement and loyalty.

$\mathrm{H}_{4}$ : There is significant positive relationship between perceived value and OWOM.

$\mathrm{H}_{5}$ : There is significant positive relationship between perceived value and loyalty.

$\mathrm{H}_{6}$ : There is significant positive relationship between OWOM and Loyalty.

The proposed model to be examined based on the hypotheses identified for the study is presented as Figure 1.The model consist of four main constructs; customers engagement with social media, perceived value of social media marketing, OWOM, and behavioral loyalty.

Figure 1. Hypothesized Relationship between Customer Engagement, Perceived Value, OWOM and Loyalty

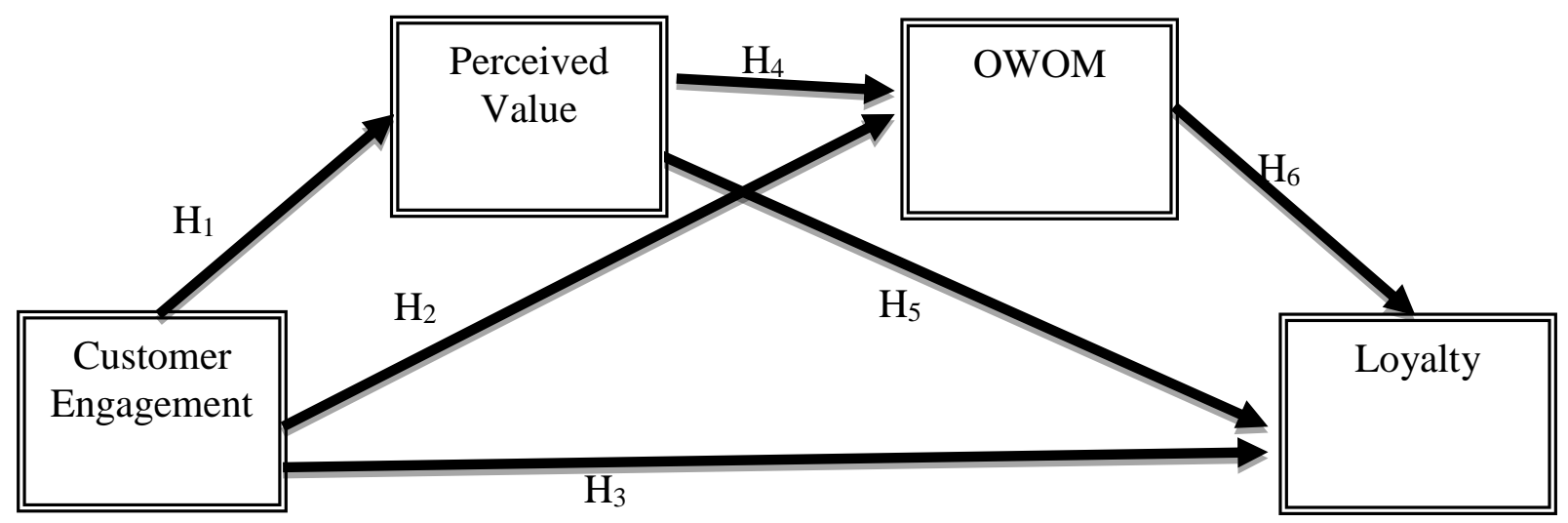

\section{Sampling}

The population of the present study is Saudi citizens having social media accounts, and are following at least one business account. These platforms were selected to be the channel of this study due to their popularity in Saudi Arabia. It is estimated that there are about 17.4 million internet users in Saudi Arabia, opening up wide opportunities for online marketing. BBC (2015), states that Saudi Arabia is the largest social media marketing nation in the Middle East region. It is estimated that there are more than eight million Facebook users and over 3.7 million active Twitter users in Saudi Arabia (Al-Khalifa, 2015). 
ENTREPRENEURSHIP AND SUSTAINABILITY ISSUES

ISSN 2345-0282 (online) http://jssidoi.org/jesi/

2019 Volume 6 Number 3 (March)

http://doi.org/10.9770/jesi.2019.6.3(32)

There is no second opinion that proper and scientific sampling is a prerequisite for a professional empirical work. According to Levine, Berenson \& Stephan (1999), 385 samples are required for a population that exceeds one million (at 95\% confident level and with 5\% standard of errors, to achieve 5 standard deviations and z-score of 1.96). Another aspect that need to be considered is the minimum number of sample required to run an accurate analysis of the PLS software. According to Hair, Hult, Ringle \& Sarstedt (2013) a minimum of 200 cases are required to generate valid results on PLS. Based on these standards, and to have a wider spread of samples, data were collected from a sample of 525 respondents. The researchers adopted a snow ball sampling technique to choose the samples. Since the questionnaire was administered online with all the statements being made essential, there was no missing data.

\section{Data collection tools}

The required data for the present study was collected through online questionnaires. Four questionnaires were used to collected data for the study, the details of which are as follows:

Table 1. Tools used for data collection

\begin{tabular}{|c|l|l|c|c|}
\hline No & \multicolumn{1}{|c|}{ Questionnaires } & Reference & No of items & Alpha \\
\hline 1 & Perceived value & & 16 & .765 \\
& $1 . \quad$ Economic & Sweeney, et al (2001) & 4 & .739 \\
& $2 . \quad$ Social & & 4 & .770 \\
& $3 . \quad$ Emotional & & 4 & .777 \\
\hline 2 & $4 . \quad$ Functional & Harris, et al (2008) & 6 & .802 \\
\hline 3 & Loyalty & Filieri(2015) & 4 & .747 \\
\hline 4 & Customer engagement & Sjöqvist(2015) & 4 & .762 \\
\hline
\end{tabular}

The questionnaires were administered after being translated into Arabic language, for a better understanding. The questionnaires had a 5 point scalewhich ranged from "Agree Strongly" to "Disagree Strongly", with the former indicating higher value. The respective developers of the questionnaires have presented high Conbrach Alpha for their tools. However, for the sake of assessing the suitability of the tool in the Saudi conditions, the Alphas were assessed (Table 1). It can be observed that the Alphas of all the tools are above the stipulated .70 (Nunally, 1978), thus enjoying the required reliability. The demographics of the sample were also were collected.

IBM SPSS was used for the required data screening, cleaning and analysis. Consequent to data cleaning, Smart PLS or path coefficient analysis was conducted. Table 2 presents the characteristics and breakups of the sample utilized for the study.

The breakup of the sample is presented in Table 2. 
Table 2. Demographic particulars of the sample

\begin{tabular}{|c|c|c|c|}
\hline \multicolumn{2}{|r|}{ Particulars } & Number & Per cent \\
\hline \multirow{6}{*}{ Age in years } & Under 20 & 63 & 12 \\
\hline & 20 to 29 & 168 & 32 \\
\hline & 20 to 39 & 126 & 24 \\
\hline & 40 to 49 & 126 & 24 \\
\hline & Above 49 & 42 & 8 \\
\hline & Total & 525 & 100 \\
\hline \multirow{6}{*}{ Educational qualification } & High school & 21 & 4 \\
\hline & High diploma & 63 & 12 \\
\hline & Graduation & 294 & 56 \\
\hline & Master & 126 & 24 \\
\hline & Doctorate & 21 & 4 \\
\hline & Total & 525 & 100 \\
\hline \multirow{6}{*}{$\begin{array}{l}\text { Annual Income in Saudi } \\
\text { Riyal }\end{array}$} & Less than 50,000 & 2 & 0.4 \\
\hline & From 50,000 to $1,00,000$ & 103 & 19.6 \\
\hline & From $1,00,001$ to $1,50,000$ & 210 & 40.0 \\
\hline & From $1,50.001$ to $2,00,000$ & 147 & 28.0 \\
\hline & Above $2,00,000$ & 63 & 12.0 \\
\hline & Total & 525 & 100 \\
\hline \multirow{6}{*}{$\begin{array}{l}\text { Usage of social media } \\
\text { (Hours per week) }\end{array}$} & Less than 10 & 42 & 8 \\
\hline & 10 to 19 & 21 & 4 \\
\hline & 20 to 29 & 210 & 40 \\
\hline & 30 to 39 & 168 & 32 \\
\hline & 40 and above & 84 & 16 \\
\hline & Total & 525 & 100 \\
\hline
\end{tabular}

It can be observed from the demographics presented in the above able that there is wide diversity with respect to the sample collected and is representative in nature.

\section{Results and Discussions}

\section{Descriptive Analysis}

The descriptive statistics are presented in Table 3.

Table 3. Descriptive statistics

\begin{tabular}{|c|l|r|r|r|r|r|}
\hline No & \multicolumn{2}{|c|}{ Variable/Factor } & \multicolumn{1}{c|}{ Min. } & \multicolumn{1}{c|}{ Max. } & Mean & \multicolumn{1}{c|}{ SD } \\
\hline \multirow{3}{*}{$\mathbf{1}$} & \multirow{2}{*}{$\begin{array}{l}\text { Perceived } \\
\text { value }\end{array}$} & Economic & 1.00 & 5.00 & 3.4400 & .98654 \\
\cline { 3 - 6 } & & Social & 1.00 & 5.00 & 3.5833 & .85735 \\
\cline { 2 - 6 } & & Emotional & 1.00 & 5.00 & 3.3924 & .93431 \\
\cline { 2 - 6 } $\mathbf{2}$ & Loyalty & Functional & 1.00 & 5.00 & 3.5600 & .90993 \\
\hline $\mathbf{3}$ & OWOM & 1.00 & 5.00 & 3.6866 & .84713 \\
\hline $\mathbf{4}$ & Customer engagement & 1.00 & 5.00 & 3.7771 & .91783 \\
\hline
\end{tabular}

Note: $\mathrm{N}=525$ 


\section{Measurement model}

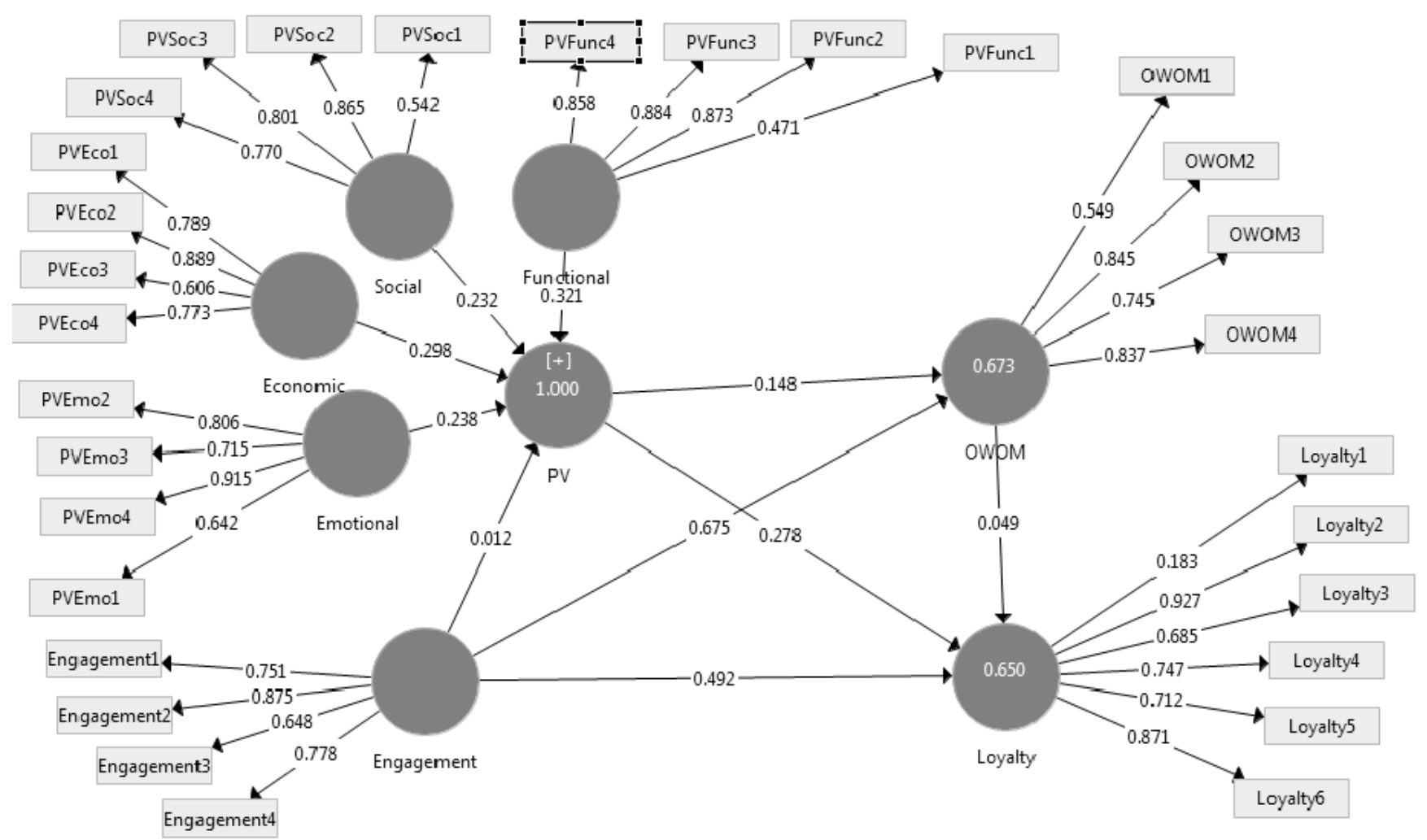

Figure 2. Measurement model

Great care has been exercised while arriving at the model for the study. This is all the more important in the case of a causal model, which attempts to explain how changes on the part of variable(s) could cause changes other variable(s). Based on established norms (for instance, Lowry and Gaskin, 2014), the causal inferences were made based on the three assumptions of covariation, non existence of probable spurious relationships, and the "temporal precedence".

Since there were issues with respect to the measurement model a few items with comparatively low values had to be dropped. This has helped in arriving at a better model. The final model with the various effects and the explained variances in the endogenous constructs are presented as Figure 3. 


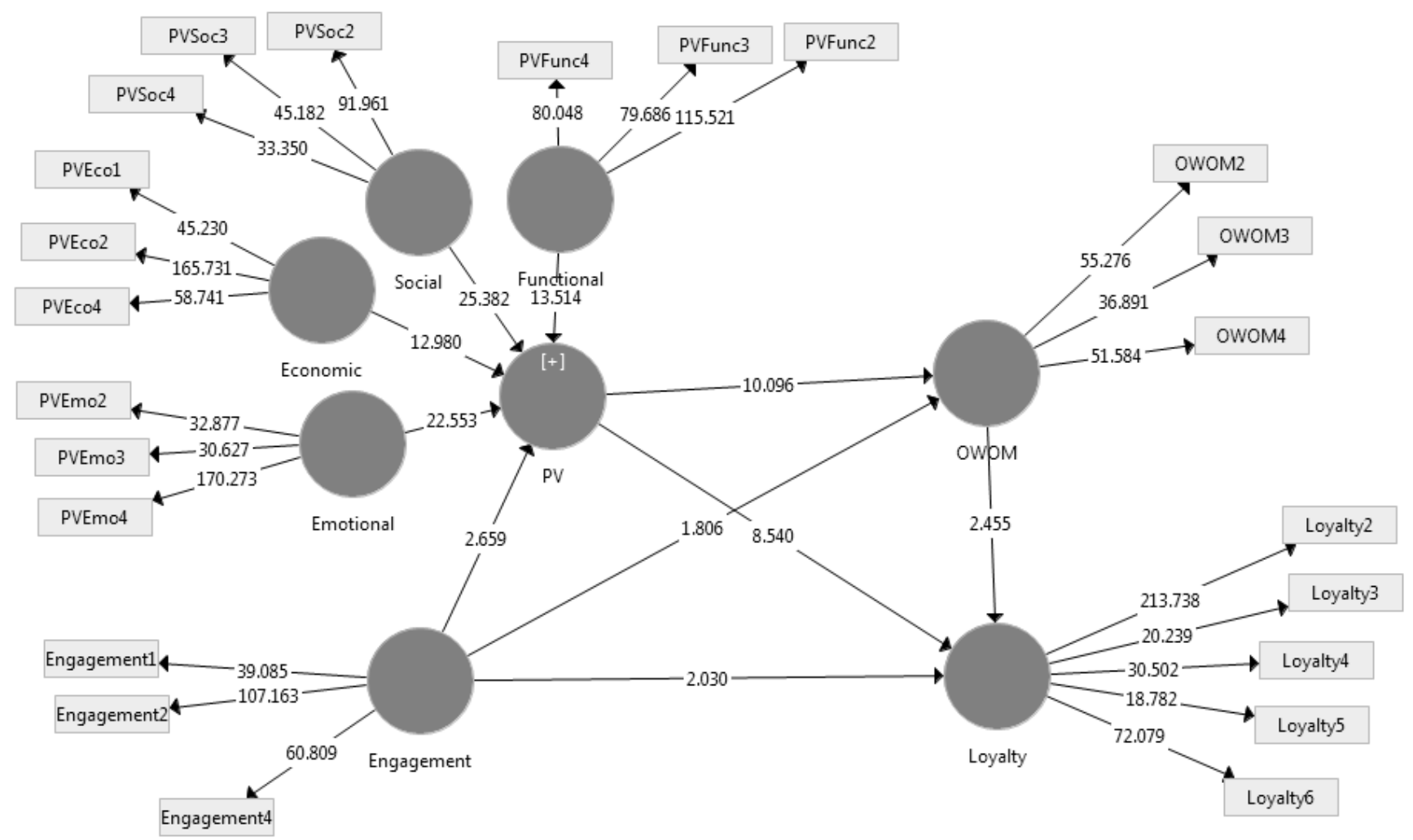

Figure 3. $\quad$ Final model

The measuring model is based on convergent and discriminant validities, and internal consistency reliability (Ringle, Silva, andDiógenes de Souza, 2014). The convergent validity is obtained by observing the Average Variance Extracted (AVEs). The AVEs need to exceed the required threshold value of 0.50 (Henseler, Ringle, andSinkovics, 2009). Those which are having values below 0.50 are required to be dropped from the model. It can be observed from Table 3 that all, but the Overall PV, exceeds the threshold value of 0.50

The internal consistencies are predicted by Alpha and the Composite Reliability (CR). This will help in evaluating the bias of the sample. The required threshold value for Cronbach's Alpha is 0.70(Nunally, 1978). It can be observed from Table 3 that all the variables have Alphas values above the stipulated limit. The Alphas range from .772 to .923 denoting adequate reliability. Those CR values above the rule of the thump of 0.70 are considered satisfactory (Hair et al., 2010). From Table 3, it can be seen that all CR values are above the required threshold limit. The CR values are found to range from 0.868 to 0.934 . These values satisfactorily meet the stipulated threshold. 
ENTREPRENEURSHIP AND SUSTAINABILITY ISSUES

ISSN 2345-0282 (online) http://jssidoi.org/jesi/

2019 Volume 6 Number 3 (March)

http://doi.org/10.9770/jesi.2019.6.3(32)

Table 3. Descriptive Statistics of Summated Scales

\begin{tabular}{|c|c|c|c|c|}
\hline $\begin{array}{c}\text { Variables/ } \\
\text { Factors }\end{array}$ & $\begin{array}{c}\text { Average } \\
\text { Variance } \\
\text { Extracted (AVE) }\end{array}$ & Cronbach'sAlpha & $\begin{array}{c}\text { Square Root of } \\
\text { AVE }\end{array}$ & $\begin{array}{c}\text { Composite } \\
\text { Reliability }\end{array}$ \\
\hline PV (Economic) & 0.716 & 0.801 & 0.814 & 0.883 \\
\hline PV (Emotional) & 0.689 & 0.770 & 0.803 & 0.868 \\
\hline PV (Functional) & 0.780 & 0.859 & 0.859 & 0.914 \\
\hline PV (Social) & 0.687 & 0.772 & 0.778 & 0.868 \\
\hline Loyalty & 0.630 & 0.849 & 0.869 & 0.893 \\
\hline Engagement & 0.703 & 0.791 & 0.811 & 0.877 \\
\hline OWOM & 0.714 & 0.801 & 0.801 & 0.882 \\
\hline
\end{tabular}

The results pertaining to the discriminant validity of the scales are presented in Table 3 and 4 . The results presented in the two tables establish that the constructs identified for the study are independent of each other (Hair et al., 2016).

From Table 4 it can be observed that the values of Square Root of AVEs (presented in the diagonals of the table)for all the indentified latent variablesare greater than the inter-correlations (r). These values suggest that the discriminant validity of the scales used in the study, as proposed by Fornell and Larcker (1981) is met.

Table 4. Inter-correlations (Fornell and Larcker (1981) Criterion)

\begin{tabular}{|l|c|c|c|c|}
\hline & Engagement & OWOM & PV & Loyalty \\
\hline Engagement & 0.811 & & & \\
\hline OWOM & 0.596 & 0.801 & & \\
\hline PV & 0.670 & 0.574 & 0.942 & \\
\hline Loyalty & 0.560 & 0.603 & 0.543 & 0.869 \\
\hline
\end{tabular}

The factors that have been extracted and the loadings of the items are presented as Table 5. These factor loadings indicate that all items were loaded on their respective constructs between 0.740 (lower bound) and 0.931 (upper bound) on their respective construct. These values also provide further support in the confirmation of discriminant validity of the tools used for the study. 
Table 5.

\begin{tabular}{|l|c|c|c|c|}
\hline & Economic & Emotional & Functional & Social \\
\hline PVEco1 & 0.811 & & & \\
\hline PVEco2 & 0.904 & & & \\
\hline PVEco4 & 0.820 & & & \\
\hline PVEmo2 & & 0.786 & & \\
\hline PVEmo3 & & 0.764 & & \\
\hline PVEmo4 & & 0.931 & & \\
\hline PVFunc2 & & & 0.894 & \\
\hline PVFunc3 & & & 0.890 & \\
\hline PVFunc4 & & & 0.865 & \\
\hline PVSoc2 & & & & 0.879 \\
\hline PVSoc3 & & & & 0.818 \\
\hline PVSoc4 & & & & 0.788 \\
\hline
\end{tabular}

\section{Structural Model Assessment}

On establishing the reliability and validity of the latent variables in the structural model, the assessment of the structural (inner) model was considered. For having the final structural model, bootstrapping technique was done. The results of the bootstrapping are presented in Table 6. It can be seen that all the paths maintain significant $p$ values at various levels $(\mathrm{p} \leq 0.01, \mathrm{p} \leq 0.05$ and $\mathrm{p} \leq 0.10)$. The model values are presented in Table 7 which throws further light on the complex relationship between the variables.

Table 6.

Bootstrapping results

\begin{tabular}{|l|r|r|r|r|r|}
\hline & $\begin{array}{c}\text { Original } \\
\text { Sample }\end{array}$ & \multicolumn{1}{c|}{$\begin{array}{c}\text { Sample } \\
\text { Mean }\end{array}$} & $\begin{array}{c}\text { Standard } \\
\text { Deviation }\end{array}$ & t-value & P Values \\
\hline Economic -> PV & 0.184 & 0.184 & 0.014 & 12.980 & 0.000 \\
\hline Emotional -> PV & 0.249 & 0.248 & 0.011 & 22.553 & 0.000 \\
\hline Functional -> PV & 0.344 & 0.345 & 0.025 & 13.514 & 0.000 \\
\hline Social -> PV & 0.267 & 0.267 & 0.011 & 25.382 & 0.000 \\
\hline Engagement -> Loyalty & -0.259 & -0.257 & 0.128 & 2.030 & 0.042 \\
\hline Engagement -> OWOM & -0.187 & -0.186 & 0.104 & 1.806 & 0.071 \\
\hline Engagement -> PV & 0.064 & 0.063 & 0.024 & 2.659 & 0.008 \\
\hline OWOM -> Loyalty & 0.115 & 0.114 & 0.047 & 2.455 & 0.014 \\
\hline PV -> Loyalty & 0.957 & 0.956 & 0.112 & 8.540 & 0.000 \\
\hline PV -> OWOM & 0.925 & 0.924 & 0.092 & 10.096 & 0.000 \\
\hline
\end{tabular}


ENTREPRENEURSHIP AND SUSTAINABILITY ISSUES

ISSN 2345-0282 (online) http://jssidoi.org/jesi/

2019 Volume 6 Number 3 (March)

http://doi.org/10.9770/jesi.2019.6.3(32)

\begin{tabular}{|l|c|c|c|}
\hline \multicolumn{1}{|c}{ Table } & $\mathbf{7 .}$ Model values \\
\hline Engagement $>$ PV & $\mathbf{R}^{\mathbf{2}}$ & $\boldsymbol{\beta}$ & F value \\
\hline Engagement -> Loyalty & .941 & .970 & 8392.234 \\
\hline Engagement -> OWOM & .577 & .760 & 713.280 \\
\hline PV -> OWOM & .634 & .796 & 904.931 \\
\hline PV -> Loyalty & .774 & .868 & 781.071 \\
\hline OWOM -> Loyalty & .743 & .743 & 643.386 \\
\hline
\end{tabular}

Note: All $F$ values are significant

\section{Structural model analysis}

As a final step of analyzing the structural model, the standardized root mean square residual (SRMR) was assessed to arrive at the goodness of fit (Henseler, Ringle and Sarstedt, 2015; Hu and Bentler, 1998). The PLS analysis has served the dual purpose and hassucceeded in establishing the validity of the instruments used for the study, as well as the theoretical relationships among the variables (nomology).

\section{Results based on hypothesis}

An examination of the structural model has also highlighted, beyond doubt, the positive relations between variables studied. The significance found in the structural coefficients and the size of effects provides the required guidelines for the results, based on research hypothesis formulated for the study. All the hypotheses formulated for the study is accepted, revealing the complex relations between the variables studied. The findings have providing further insights regarding the behavior of consumers regarding OWOM and customer loyalty. The results based on the hypothesis are presented below:

$$
\begin{aligned}
& \mathrm{H}_{1}: \mathrm{CE}->\mathrm{PV} . \\
& \mathrm{H}_{2}: \mathrm{CE}->\mathrm{OWOM} \text {. } \\
& \mathrm{H}_{3}: \mathrm{CE}->\text { Customer Loyalty. } \\
& \mathrm{H}_{4}: \mathrm{PV}->\mathrm{OWOM} \text {. } \\
& \mathrm{H}_{5}: \mathrm{PV}->\text { Loyalty. } \\
& \mathrm{H}_{6}: \text { OWOM-> Customer Loyalty. }
\end{aligned}
$$

\section{Research Significance}

The findings of the study have provided some significant insights to both academic and business fields. This significance is all the more important since there are paucity of studies in the area of social media marketing in the Saudi context. Moreover, the present study is one of the few studies that have investigated the perceived value of social media marketing, in general, and OWOM in particular. The study has also provided deep understanding of the online behavior loyalty and the factors that influence it i.e. OWOM and perceived value of social media marketing.

The practical contribution of this study provides insight to marketing managers and online communication specialist to enhance the current practices of social media marketing in order to communicate marketing messages in efficient and effective way. Finally, it has also provided contextual contribution to better understand the online consumers' behaviors, which will, in turn, facilitate the promotion of better business environment in Saudi Arabia. This finding can also be generalized to other contexts that share similar characteristics i.e. Islamic, Arabic and developing countries. 


\section{ENTREPRENEURSHIP AND SUSTAINABILITY ISSUES}

ISSN 2345-0282 (online) http://jssidoi.org/jesi/

2019 Volume 6 Number 3 (March)

http://doi.org/10.9770/jesi.2019.6.3(32)

\section{Conclusion}

The present study has made several significant contributions to online marketing literature and to the business practices as well. The study has succeeded in enhancing the current understanding of the perceived value of social media marketing in Saudi Arabia in particular and the field of Social media marketing in general. This is expected to have profound impact on both academic field and business practices. Being the first study to be conducted in the Saudi context, it provides further significance and is of paramount importance.

That the study has empirically examined the influence of OWOM on behavioral attitudes of consumers also is of profound importance to marketing literature. This examination has successfully responded to the recommendation of Daun et al. (2008). Thus it succeeded in filling the knowledge gap in this area. The significance of the study emerges from the fact that previous studies have either examined the influence of OWOM or the perceived value of social media marketing. The present work has succeeded in developing an integrated framework that ahs encompassedcertain important constructswithin the same model. This can be considered as an original contribution to knowledge, which will help in improvingthe current practices in this direction. That the Islamic characterizes are unique in nature has been established in many earlier studies (Shalaby, 2008). As the study has absorbed the unique culture and distinct Islamic characteristics of the Saudi contexts, it is expected to open up the concept to a wider horizon and the consequent further examination.

The revealing of the complex relationship of OWOM with the other examined factors will go a long way in contributing towards better practices in local, regional and international businesses in the area of social media marketing. It is expected that the results of present study, which has empirically proved the complex interrelationships will promote superior practices in the area of social media marketing in Saudi Arabia. Though there is a need of generalization, it can be inferred that the findings would be applicable among other Islamic, Arabic and developing counties. Further, it is also expected that the result of the study will induce in the minds of researches the inquisitiveness to explore deeper into this interesting topic.

\section{References}

Andreassen, T. W. and Streukens, S. (2009). Service Innovation and Electronic Word-of-Mouth: Is it Worth Listening To? Managing Service Quality, 19(3), 249-65.

Bhatnagar, A. and Ghose, S. (2004). Online Information Search Termination PatternsAcross Product Categories and Consumer Demographics. Journal of Retailing, 80 (3), 221-8. http://dx.doi.org/10.1016/j.jretai.2003.10.001

Blazevic, V., Hammedi, W., Garnefeld, I., Rust, R. T., Keiningham, T., Andreassen, T. W., Donthu, N. and Carl, W. (2013). Beyond Traditional Word-of-Mouth: An Expanded Model of CustomerInfluence. Journal of Service Management, 24(3), $294-313$.

Chen, Y., Xie, J. (2004).Online Consumer Review: A New Element of Marketing Communications Mix. Working Paper, Department of Marketing, University of Florida.

Dellarocas, C. N. (2003). The Digitization of Word-of-Mouth: Promise and Challenges of Online Feedback Mechanisms. Management Science, 49(10), 1407-24. http://ccs.mit.edu/dell/digitization\%20of\%20word-of-mouth.pdf

Dhar, V. and Chang, E. A. (2009). Does Chatter Matter? The Impactof User-Generated Content on Music Sales. Journal of Interactive Marketing, 23(4), 300-7.

Duana, W., Gu, B. and Whinston, A. B. (2008). The dynamics of online word-of-mouth and product sales-Anempiricalinvestigation of the movie industry. Journal of Retailing, 84(2), 233-242. http://doi:10.1016/i.jretai.2008.04.005

Ellison, G., Fudenberg, D. (1995). Word-of-Mouth Communication and Social Learning. Quarterly Journal of Economics, 110(1), 93-125. 


\section{ENTREPRENEURSHIP AND SUSTAINABILITY ISSUES}

ISSN 2345-0282 (online) http://jssidoi.org/jesi/

2019 Volume 6 Number 3 (March)

http://doi.org/10.9770/jesi.2019.6.3(32)

Fishburn, PC, 1970. Utility theory for decision making, Wiley, New York.ed.

Fletcher, H.D, Smith, Fornell, C., and Larcker, D.F. (1981). Evaluating structural equation models with unobservable variables and measurement error. Journal of Marketing Research, 18(1), 39-50. https://doi.org/10.2307/3151312

Godes, D and Mayzlin, D. (2004). Using Online Conversations to StudyWord of Mouth Communication. Marketing Science, 23(4), 54560. https://doi.org/10.1287/mksc. 1040.0071

Godes, D.and Silva, J. C. (2012). Sequential and Temporal Dynamics of OnlineOpinion. Marketing Science, 31(3), 448-73.

Hair, J. F., Hult, G. T. M., Ringle, C., \&Sarstedt, M. (2016). A primer on partial least squares structural equation modeling (PLS-SEM): Sage Publications.

Henseler, J., Ringle, C. M., and Sinkovics, R. R. (2009). The use of partial least squares path modeling in international marketing New challenges to international marketing (pp. 277-319): Emerald Group Publishing Limited.

Henseler, J., Ringle, C. M., and Sarstedt, M. (2015). A new criterion for assessing discriminant validity in variance-based structural equation modeling. Journal of the Academy of Marketing Science, 43(1), 115-135. https://doi.org/10.1007/s11747-014-0403-8

King, R. A., Racherla, P.and Bush, V. D. (2014). What We Know and Don't Know About Online Word-of-Mouth: A Review and Synthesis of the Literature. Journal of Interactive Marketing, 28, 167-183. http://dx.doi.org/10.1016/j.intmar.2014.02.001

Kozinets, R. V., De Valck, K., Wojnicki, A. C. and Wilner, S. J. S. (2010). Networked Narratives: Understanding Word-of-Mouth Marketing in Online Communities. Journal of Marketing, 74(2), 71-89. https://doi.org/10.1509/jmkg.74.2.71

Kusumasondjaja, S. (2018). The roles of message appeals and orientation on social media brand communication effectiveness: An evidence from Indonesia. Asia Pacific Journal of Marketing and Logistics, 30(4), 1135-1158. https://doi.org/10.1108/APJML-10-2017-0267

Laroche, M., Yang, S., McDougall, G. H.G. and Bergeron, J. (2005). Internet Versus Bricks-and-Mortar Retailers: An Investigationinto Intangibility and Its Consequences. Journal of Retailing, 81(4), 251-67.

Lowry, P. B. and Gaskin, J. (2014). Partial Least Squares (PLS) Structural Equation Modeling (SEM) for Building and Testing Behavioral Causal Theory: When to Choose It and How to Use It. IEEE Transactions on Professional Communication, 57(2), 123-146.

Maxham, J. G. Jr. and Netemeyer, R. G. (2002). Modeling Customer Perceptions of Complaint Handling Over Time: The Effects of PerceivedJustice on Satisfaction and Intent. Journal of Retailing, 78, 239-52. Available at http://thecustomerconnection.nl/docs/Maxham\%20III\%20\&\%20Netemeyer\%20-

\%20Modeling\%20customer\%20perceptions\%20of\%20complaint\%20handling\%20over\%20time.pdf

Nunnally, J. C. (1978). Psychometric theory (2nd Ed.), New York: McGraw-Hill Book Company.

Ringle, C. M., Silva, D. D, \& Diógenes de Souza, B. (2014). Structural Equation Modeling with the Smart PLS. REMark: Revista Brasileira de Marketing, 13(2), 56-73. http://dx.doi.org/10.5585/remark.v13i2.2717

Senecal, S., Nantel, J. (2004). The Influence of Online ProductRecommendations on Consumers' Online Choices. Journal of Retailing, 80, 159-6.

Tirunillai, S., Tellis, G. J. (2012). Does Chatter Really Matter? Dynamics of User-Generated Content and Stock Performance. Marketing Science, 31(2), 198-215. http://dx.doi.org/10.1287/mksc.1110.0682

Trusov, M., Bucklin, R. E., Pauwels, K. (2009). Effects of Word-of-Mouth Versus Traditional Marketing: Findingsfrom an Internet Social Networking Site. Journal of Marketing, 73(5), 90-102. 


\section{ENTREPRENEURSHIP AND SUSTAINABILITY ISSUES}

ISSN 2345-0282 (online) http://jssidoi.org/jesi/

2019 Volume 6 Number 3 (March)

http://doi.org/10.9770/jesi.2019.6.3(32)

\section{Aknowledgements}

This project was supported by the Deanship of Scientific Research at Prince Sattam Bin Abdulaziz University under the resarcch project \# 2016/01/5721

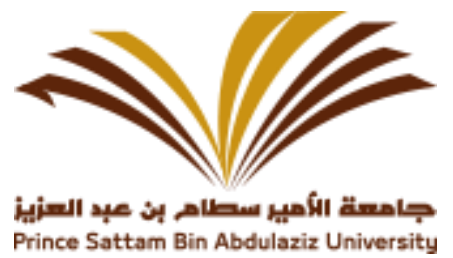

Short biographical note about the contributors at the end of the article (name, surname, academic title and scientific degree, duties, research interests):

Dr. Ahmed S. AJINA is Asst. Professor at College of Business Administration of Prince Sattam Bin AbdulazizUnviersity, Al-Kharj, Saudi Arabia. He is currently the Dean of the College. Research interests: Marketing, Social media marketing, E-business, etc. https://orcid.org/0000-0001-8839-5358

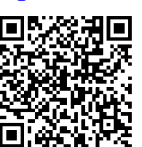

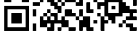

Register for an ORCID ID:

https://orcid.org/register

Copyright (C) 2019 by author(s) and VsI Entrepreneurship and Sustainability Center

This work is licensed under the Creative Commons Attribution International License (CC BY).

http://creativecommons.org/licenses/by/4.0/

(c) (i) Open Access 